\title{
The mediating role of managerial accounting in non-profit organizations: a structural equation modelling approach
}

\author{
Ivana Perica ${ }^{1}$ \\ ${ }^{1}$ University of Split, Faculty of Economics, Business and Tourism, Cvite Fiskovića 5, 21 000, Split, \\ Croatia \\ E-mail: 〈iperica@efst.hr〉
}

\begin{abstract}
Structural equation modelling (SEM) characteristics seem to be adapted to answer various relevant research questions in management accounting research. Thus, this study aims to illustrate the use and advantages of SEM in management accounting research in the non-profit sector. The contributions of this study include revealing the relationship between the leadership style, managerial accounting, and the performance of non-profit organizations measured by their community engagement. Furthermore, the mediating role of managerial accounting in non-profit organizations is also investigated in this context. The empirical results prove the existence of direct relationships between analytical and proactive leadership style and managerial accounting on the one hand and between managerial accounting and successful community engagement of non-profit organizations (non-financial performance) on the other. The study also confirms that managerial accounting mediates the relationship between the analytical and proactive leadership style and successful community engagement of non-profit organizations. The findings provide a valuable insight to guide managers in non-profit organizations and improve their non-financial performance through managerial accounting.
\end{abstract}

Keywords: non-profit organizations, managerial accounting, structural equation modelling

Received: November 8, 2021; accepted: November 26, 2021; available online: December 23, 2021

DOI: $10.17535 /$ crorr.2021.0012

\section{Introduction}

Non-profit organizations have a specific scope of business activities, so they need more detailed information about these processes, which is generated by the managerial accounting system. Eldenburg and Krishnan [9] and Hopper and Bui [14] point out a surprisingly limited number of studies on managerial accounting in the non-profit sector. They also emphasize the need for non-profit organizations to effectively adopt managerial accounting that will enable information to improve the non-profits' performance. Managerial accounting in non-profit organizations cannot be a literal application of its techniques used in for-profit organizations or public sector organizations. Managerial accounting in non-profit organizations mainly focuses on connecting the source of funds with the destination, i.e., the efficient use of funds [8].

This study relies on a contingency approach and aims to determine how the contingency factor as a decision-making style influences managerial accounting in non-profit organizations. Furthermore, the study seeks to examine how managerial accounting affects the performance of non-profit organizations and investigates the mediating role of managerial accounting between an executive's decision-making style and the performance of non-profit organizations.

The concept of performance in the non-profit sector is still elusive and contested [13] because no universal standard can apply to conceptualization to date. The performance of non-profit organizations still has different meanings depending on how an individual organization defines 
success [34]. This study focuses only on one particular dimension of the non-profit's organizational performance, i.e., success in community engagement, which to a large extent reflects their mission goals.

The study employs the structural equation modelling technique on the data collected from a sample of 416 non-profit organizations in Croatia. Recently, the dominant tool in managerial accounting research has been the structural equation modelling (SEM). SEM is a methodology that allows: (1) running the Confirmatory Factor Analysis (CFA), (2) analysing multiple regression models simultaneously, (3) analysing regressions with the multicollinearity problem, (4) conducting the path analysis with multiple dependents, (5) estimating the correlation and covariance in a model, (6) modelling the inter-relationships among variables in a model, and (7) testing the hypotheses for mediators and moderators in a model [1]. SEM is appropriate for management accounting research in the non-profit sector because it represents a method that can define unobservable conceptual variables like contingency factors, managerial accounting techniques, and non-financial performance.

By applying SEM, this study improves the research methodology in managerial accounting research in the non-profit sector because SEM is used to evaluate both unobserved and observed variables and allows the simultaneously construct-measure relationship and constructto-construct relationship to be evaluated. Furthermore, this research has a mediator in the model and SEM enables mediation relationships to be properly examined. By using SEM, this study examines a series of dependence relationships simultaneously and brings a higher-level perspective to managerial accounting in the non-profit sector.

Although there has been a growing interest in managerial accounting research in the forprofit sector $[2,5,15,4,22,28,31]$, research that examines the effects of managerial accounting techniques on non-profit's performance is still scarce. Therefore, the main objectives of this study are: (1) to analyze the relationship between the manager's decision-making style and the application of managerial accounting in non-profit organizations, (2) to analyze the relationship between the application of managerial accounting and the level of community engagement a proxy for non-profits' organizational performance, and (3) to investigate the mediating role of managerial accounting between an executive's decision-making style and the performance of non-profit organizations. This study contributes to the managerial accounting literature by responding to recent calls to investigate the effects of managerial accounting in the non-profit sector. This study represents one of the rare studies that explore managerial accounting techniques in non-profit organizations. It provides empirical evidence that managerial accounting is a mechanism that supports the performance of non-profit organizations.

The structure of this study is as follows. In the second section, the theoretical background is presented, followed by the development of hypotheses. Methodology and data are explained in the third section, followed by the results and discussion. The final section presents the concluding remarks.

\section{Theoretical background and hypotheses development}

In accounting, managerial decision-making style is a critical contingency factor because managers' ability to use accounting information allows them to understand the basic accounting processes that affect the effectiveness of decision-making [20]. Connor and Becker [7] identified four types of the managerial decision-making style: (1) the analytical style characterizes managers who use more information and variants in problem - solving; (2) the directive decision-making style characterizes managers who make quick decisions and focus on the short term, do not use a large amount of information, and assess a small number of opportunities; (3) the conceptual style characterizes managers who are creative and prone to risk; (4) the behavioral style where performance arises from focusing on people and their needs. The managerial decision-making 
style factor has been neglected in management accounting research in the non-profit sector. It is common knowledge in the accounting literature that information users have different preferences for information and processing capabilities due to different models, decision-making styles, and cognitive decision-making characteristics [29], so it is reasonable to assume:

H1. Analytical and proactive manager's decision-making style is positively related to the application of managerial accounting in non-profits.

In managerial accounting research on the for-profit and public sectors, many studies have examined the relationship between the level of application of managerial accounting and the achievement of organizational performance. Numerous studies have provided evidence that a higher level of application of managerial accounting leads to better performance [32, 22, 21, 27, 31]. Managerial accounting studies in the non-profit sector are scarce. Studies in the non-profit sector generally point to the importance of applying managerial accounting and prescribing tools and techniques used in managerial accounting to improve efficiency. Ip, Li, and Yau [17] found that the activity-based costing enables staff yields better results. Pizzini [25] conducted an empirical research on the sample of non-profit hospitals and proved that providing detailed cost information is positively related to improved financial performance. Ryan and Irvine [26] suggested that transparent disclosure of cost information can improve public trust in nonprofit organizations. Henderson and Lambert [12] carried out a case study analysis where the managerial accounting system appears to enhance the process of decision-making in charities. In light of the limited prior empirical findings in the non-profit sector, which is consistent with the reported positive relationship between the application of managerial accounting and organizational performance in the for-profit and public sectors, the following hypothesis is developed:

H2. The application of managerial accounting in non-profits is positively related to the level of community engagement - a proxy for non-profits organizational performance.

Previous research that has linked the mediating effect of the application of managerial accounting and performance is mainly related to the for-profit sector. The studies in the for-profit sector have identified supporting evidence for the mediating impact of managerial accounting between contingency factors and performance achievement. Thus, Bouwens and Abernethy [2] concluded that a managerial accounting system can assist managers in resolving the uncertainty associated with decision-making. Hoque [15] found a significant and positive association between strategic decisions and successful business when the managers use accounting information. In their study, Cadez and Guilding [4] confirmed the mediating influence of managerial accounting between contingency factors such as strategy and size of the organization and the performance achieved. A study by Teeratansirikoola et al. [28] also provides an insight into the mediating role of managerial accounting in terms of competitive strategic priorities and organizational performance. Although evidence of the mediating effect of managerial accounting exists in the for-profit sector, the literature base in the non-profits area remains sparse. Wadongo and Abdel Kaber [33] claim that the managerial accounting system implemented in non-profit organizations should improve the efficiency by enabling managers to better deal with the external environment and specificities within the organizations themselves. In light of the limited prior empirical findings in the non-profit sector, the following hypothesis about the mediating role of managerial accounting in the non-profit sector has been motivated by the evidence in the for-profit sector. Regardless of the direct relationships set in the first two hypotheses, this research also assumes a mediating effect of managerial accounting system between manager's decision-making style as the contingency factor and the dimension of the non-profit's organizational performance, i.e., success in community engagement. Therefore, the research is based on the assumption that non-profit organizations with an analytical and proactive manager will be more successful in community engagement through the mediation effects of managerial accounting. 
The following hypothesis is developed:

H3. Managerial accounting in non-profits mediates the effect of the analytical and proactive manager's style of decision-making on the success in community engagement.

\section{Methodology and Data}

Empirical research was conducted using a questionnaire survey. An online questionnaire was e-mailed to 1,057 non-profit organizations in Croatia. Only those non-profit organizations that use the double-entry bookkeeping and have more ten employees/volunteers were selected for the sample. An e-mail with a link to the online questionnaire was sent to the executives of non-profit organizations because they were expected to have access to a wide range of business information and have sufficient information about the application of managerial accounting in organizations. The survey consisted of several parts. The first part included questions on the manager's decision-making style. The measure used draws on Gordon and Miller's [10] characteristics of a manager's decision-making style: (1) decision analysis, (2) decision time horizons, (3) complex decision making, (4) proactivity, and (5) strategy awareness. The respondents were asked to indicate the degree of agreement with a particular statement concerning these five aspects of decision-making. The five-point Likert scale ranged from "1" (strongly disagree) to "5" (strongly agree). The second part of the survey referred to questions on the managerial accounting techniques. The usage level of managerial accounting techniques was measured using a slightly modified approach by King, Clarkson, and Wallace [18], following the question, "How systematically does the organization use the following management accounting techniques? ". The techniques were listed together with a Likert-type scale ranging from "1" (not at all) to "5" (every week). The third part of the survey encompassed questions on a particular dimension of the non-profit's organizational performance, i.e., success in community engagement. Success in community engagement was measured using a modified version of Mitchell [23] and Colbran et al. [6]. Two additional dimensions were added: (1) "the success of the participation in influencing public policy" and (2) "the success in initiatives to create an enabling environment for developing the civil society." For each dimension, the respondents were asked to indicate their agreement related to the success in community engagement on a scale ranging from " 1 " (strongly disagree) to "5" (strongly agree). The last part of the survey referred to the socio-demographic characteristics. A total of 416 responses were received to the e-mails sent. There was no missing data. Thus, the overall response rate was $39.36 \%$. Non-profit organizations represented in the sample include $86.3 \%$ associations, $7.7 \%$ institutions, $1.9 \%$ religious organizations, and 1 $\%$ chambers. Out of the total surveyed non-profit organizations, $3.1 \%$ represent other nonprofit organizations such as foundations, cooperatives, etc. The non-profit's managers from the sample are mostly of a younger age. Namely, $53.8 \%$ of the respondents are below 45 years of age, and $28.6 \%$ are between 46 and 55 years of age. Over $50 \%$ of the managers from the sample have more than ten years of experience in the non-profit sector. Most of them (57 \%) have been holding managerial positions in the non-profit sector for more than six years, which indicates that the non-profit's managers from the sample have experience in managing non-profit organizations.

Covariance-based structural equation modelling (with AMOS 23.0) was applied to test the proposed hypotheses. Structural equation modelling (SEM) is a multivariate technique that allows a set of relationships between the variables to be examined, based on variates in the measurement and structural models [11]. SEM is not unrelated to statistical models such as analysis of variance (ANOVA), multiple regression analysis, and principal factor analysis because SEM represents the generalization, integration, and extension of these familiar models [16]. This statistical technique can be helpful in managerial accounting research because empirical research in managerial accounting often involves a complex set of different variables. 
Although ANOVA and multiple regression analysis can accommodate numerous dependent variables, they are limited in how the relations between those variables are specified; in ANOVA and multiple regression analysis, the variable can be the independent or dependent variable, but not both [16]. SEM can handle both analytical situations. Furthermore, SEM enables a more explicit conceptualization of the theory under study because the hypothesized model can be tested statistically in simultaneous analysis of the entire system of variables to determine the extent to which it is consistent with the data [3]. Accordingly, several aspects of SEM set it apart from other multivariate techniques [19, 3, 24]: (1) SEM provides precise estimates of error variance parameters, unlike traditional multivariate techniques, which are incapable of either assessing or correcting measurement errors, (2) using SEM procedures can incorporate both unobserved and observed variables, (3) SEM allows the evaluation of entire models, which brings a higher-level perspective to the analysis, (4) there are no widely applied alternative methods for modelling multivariate relations or estimating indirect effects, and these features are available using SEM methodology, (5) the SEM family is a highly flexible set of techniques, applicable to both experimental and nonexperimental data, and (6) SEM offers flexibility for testing mediation and moderation relationships.

\section{Results and discussion}

The preliminary evaluation of scales was done using the exploratory factor analysis (EFA). EFA was performed on 15 items to interpret the factor structure. Bartlett's test $(\chi 2=2,569.156$, $\mathrm{P}<0.001)$ and KMO (0.831) supported the factorability of the item set, indicating the adequacy of sampling. The principal component analysis and the Varimax rotation technique were used to identify the underlying dimensions of the constructs. Kaiser's rule identified three factors. A 3-factor solution produced factors that corresponded to managerial accounting (MA), analytical and proactive manager's style (APMS), and community engagement (CE). The solution explained $61.268 \%$ of the variance in the data. All items loaded on the corresponding factors with factor loadings higher than 0.5 , and all items had clean loadings.

\subsection{Measurement model}

The first part of the analysis aimed to investigate the best measurement model. Confirmatory factor analysis was conducted with the model of structural equations, i.e., in the measurement model, with three factors and 15 variables.

Data were checked for univariate and multivariate normality. The Kolmogorov-Smirnov test indicated the non-normality of all variables. The skewness and kurtosis measures of most of the variables are within the -2 and +2 acceptable range. Exceptions are variables CE3 (2.267) and APMS3 (3.482) that thus exhibit a degree of non-normality. However, in the case of multivariate normality, the results showed that the data violated the multivariate normality assumption since Mardia's coefficient was higher than 5 and the critical value was higher than 1.96. Considering that maximum likelihood estimation (MLE) rests on the assumption of multivariate normality, the evidence of multivariate non-normal distributions required Bootstrapping resampling procedure when evaluating the structural model. Data were also checked for outliers by using the Mahalanobis distance, and the results showed outliers. However, when the reasons for the irregularity of the results cannot be determined, according to Thompson's [30] recommendation, it is not reasonable to delete the grades just because of the atypicality of deviations. Thus, identified outliers were not removed. So, the final sample includes 416 respondents.

The analysis in the measurement model was conducted using the statistical package AMOS Graphic 23.0.0. The estimation method was maximum likelihood (ML), assuming data normality. The N:q rule can be applied when the ML is used, and the commonly suggested ratio 
is 10:1 to 20:1 [19]. Therefore, the requirement regarding the sample size according to the number of free parameters was satisfied. Regression coefficients are fixed at 1 to achieve model identification. As for the construction in the model, reflective construction is used.

After the measurement model specification, the suitability of the assumed model was reviewed, and the majority of model fit statistics did not show proper fits. Thus, it was apparent that some modifications in the specification were needed to identify a model that represents the sample data better. Therefore, it was necessary to examine the parameter estimation and modification index and generate a new model. The initially hypothesized model was modified by adding a covariance between error terms for CE1 and CE3 and for CE1 and CE4. Goodnessof-fit statistics revealed improvement to the model fit. An assessment of the assumed model showed a Chi-square of 137.459 with df 85 . Additionally, the composite reliability (CR), average variance extracted (AVE), and Cronbach's alpha values $(\alpha)$ (Table 1 ) indicate that the unidimensionality requirement was achieved, and all items have acceptable factor loadings for the particular latent construct. The presence of convergent validity and reliability was also established.

Table 1: CFA results - convergent validity and reliability measurements for variables

\begin{tabular}{|c|c|c|c|c|c|}
\hline Factor & Item & Estimate & $\alpha$ & CR & AVE \\
\hline APMS & $\begin{array}{l}\text { I deal only with day-to-day operational issues ignoring the long- } \\
\text { term consequences. APMS3 } \\
\text { I make decisions without spending much time studying the envi- } \\
\text { ronment, problems, and opportunities. APMS2 } \\
\text { I make decisions based on my intuition ignoring objective facts. } \\
\text { APMS1 } \\
\text { I have a simple approach to decision-making without detailed as- } \\
\text { sessments and monitoring of how beneficiaries and donors behave. } \\
\text { APMS4 } \\
\text { I only act when something happens, and I don't want to influence } \\
\text { what will happen. APMS5 }\end{array}$ & $\begin{array}{l}0.768 \\
0.838 \\
0.688 \\
0.775 \\
0.635\end{array}$ & 0.86 & 0.86 & 0.55 \\
\hline MA & $\begin{array}{l}\text { The non-profit organization monitors internal performance indi- } \\
\text { cators. MA6 } \\
\text { The non-profit organization monitors overhead costs by assigning } \\
\text { them to activities. MA5 } \\
\text { The non-profit organization monitors cost by functional classifi- } \\
\text { cation. MA4 } \\
\text { The non-profit organization monitors direct and indirect project } \\
\text { costs. MA3 } \\
\text { The non-profit organization controls the budgeting of costs. MA2 } \\
\text { The non-profit organization monitors cost by the source of fund- } \\
\text { ing. MA1 }\end{array}$ & $\begin{array}{l}0.516 \\
0.686 \\
0.756 \\
0.833 \\
0.745 \\
0.656\end{array}$ & 0.85 & 0.85 & 0.50 \\
\hline $\mathrm{CE}$ & $\begin{array}{l}\text { The non-profit increases the number of new contacts for network- } \\
\text { ing and collaboration. CE3 } \\
\text { The non-profit organization increases the number of partner or- } \\
\text { ganizations that support the organization. CE2 } \\
\text { The non-profit organization successfully participates in influenc- } \\
\text { ing public policy. CE1 } \\
\text { The non-profit organization successfully participates in initiatives } \\
\text { to create a stimulating environment for the development of civil } \\
\text { society. CE4 }\end{array}$ & $\begin{array}{l}0.876 \\
0.863 \\
0.561 \\
0.514\end{array}$ & 0.78 & 0.81 & 0.52 \\
\hline
\end{tabular}

Table 1 indicates that all variables have acceptable values of the Cronbach's alpha coefficient $>0.7$ and that the condition of internal reliability was met. Composite reliability values $(\mathrm{CR}$ $>0.6$ ) confirmed the reliability and internal consistency of manifest variables that measure the latent variable. The values of mean extracted variance (AVE) range from 0.50 to 0.55. 
According to the established rule that AVE should be $>0.5$, the convergent validity of the construct was adequate. In summary, the analysis of the measurement model revealed that the assumptions of one-dimensionality, validity, and reliability were met.

Correlations among the latent variables lower than 0.85 and the roots of AVEs values (Table 2) suggest the presence of discriminant validity of the used measurement scales.

Table 2: Discriminant validity analysis of the used measurement scales

\begin{tabular}{|l|l|l|l|}
\hline & APMS & MA & CE \\
\hline APMS & $\mathbf{0 . 7 4 4}$ & & \\
\hline MA & 0.245 & $\mathbf{0 . 7 0 6}$ & \\
\hline CE & 0.217 & 0.290 & $\mathbf{0 . 7 2 3}$ \\
\hline
\end{tabular}

The CFA indicates a good fit of the model (Table 3). In the chi-square analysis, the p-value was 0.000 . It should be non-significant to indicate the fit of the model. However, chi-square is sensitive to sample size and violation of multivariate normality, so various fit indicators were considered to assess the data-model fit. The goodness-of-fit indices reflect a good fit (Table 3).

Table 3: Summary fit model

\begin{tabular}{|l|l|l|}
\hline & Indicator & Values \\
\hline \multirow{3}{*}{ Absolute fit } & Discrepancy Chi Square (Chisq p-value) & 0.000 \\
& Root Mean Square Error of Approximation (RMSEA) & 0.039 \\
& Goodness-of-Fit Index (GFI) & 0.959 \\
\hline \multirow{4}{*}{ Incremental fit } & Adjusted Goodness-of-Fit Index (AGFI) & 0.941 \\
& Comparative Fit Index (CFI) & 0.979 \\
& Tucker-Lewis Index (TLI) & 0.974 \\
& Normed Fit Index (NFI) & 0.948 \\
\hline Parsimonious fit & Chi-Square/Degrees of Freedom (Chisq/df) & 1.617 \\
\hline
\end{tabular}

As mentioned earlier, the assumption of multivariate normality was not met. Therefore, a Bollen-Stine bootstrap was performed. The Bollen-Stine was run on 2,000 bootstrap samples, and the Bollen-Stine bootstrap p-value was 0.054. Since the Bollen-Stine bootstrap p-value was insignificant $(>0.05)$, the conclusion was that the model fits the data well, even in the case of this sample with non-normally distributed data.

\subsection{Structural model}

The Structural (SEM) model (Figure 1) was performed using the bootstrap maximum likelihood estimator and was identified by three interrelated latent constructs: APMS (analytical and proactive manager's style), MA (managerial accounting), and CE (community engagement). The following figure indicates the structural relationship model. 


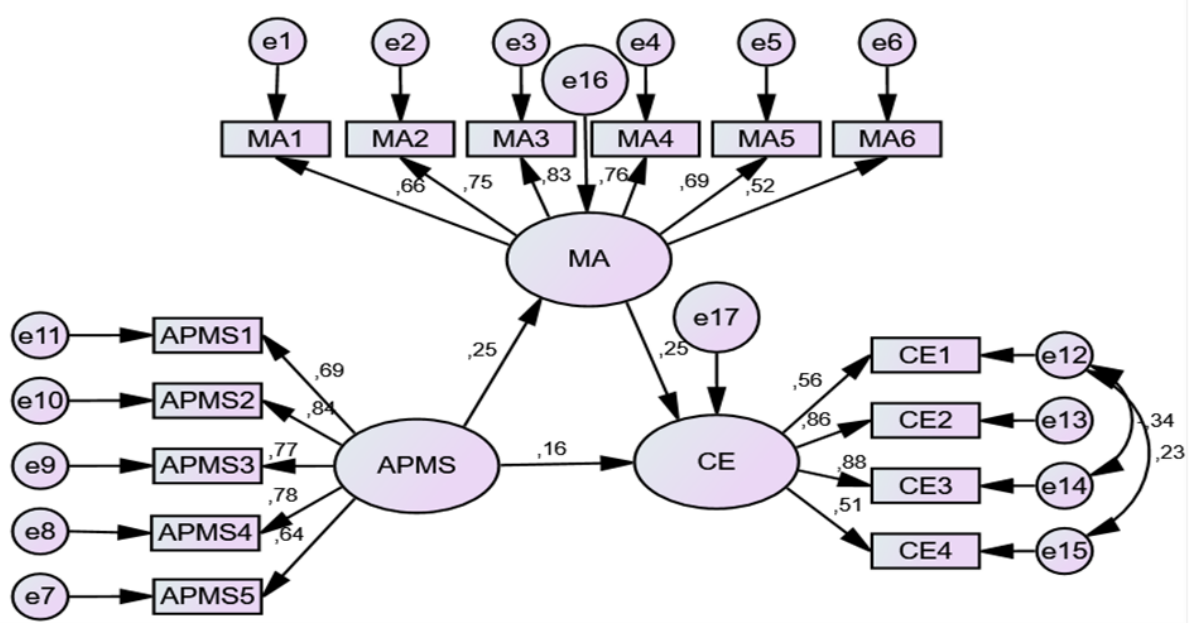

Figure 1: Structural model: standardized solution.

Before interpreting the structural relationship model (Table 4), the crucial fit tests of the created SEM model were calculated and compared with reference values. It was found that all fitness measured in this research achieved the suggested values and represented a good model fit (GFI: 0.959; RMSEA: 0.039; AGFI: 0.941; CFI: 0.979; TLI: 0.974; NFI: 0.948; Chisq/df: $1.617)$.

Table 4: Structural model results - hypothesis testing

\begin{tabular}{|l|l|l|l|}
\hline Hypothesis & Estimate & p-value & Results \\
H1 & 0.245 & $* * *$ & H1 is supported \\
H2 & 0.252 & $* * *$ & H2 is supported \\
\hline$* * * \mathrm{p}<0.001$.
\end{tabular}

As hypothesized, an analytical and proactive manager's decision-making style has a significant and positive impact on the application of managerial accounting in non-profit organizations $(\beta=0.245, \mathrm{p}<0.001)$. Additionally, the application of managerial accounting in non-profit organizations has a significant and positive impact on the level of community engagement - a proxy for non-profits' organizational performance $(\beta=0.252, \mathrm{p}<0.001)$.

Furthermore, the mediating role of managerial accounting was tested using the bootstrapping approach with 2,000 bootstrap resamples. The mediating effect was tested employing the maximum likelihood (ML) bootstrap with $95 \%$ bias-corrected confidence intervals. First, the relationship between an analytical and proactive manager's decision-making style and community engagement without managerial accounting (mediator) was tested. The results showed a significant $(\mathrm{p}<0.001)$ relationship between an analytical and proactive manager's decision-making style and community engagement. Second, the indirect effect from the analytical and proactive manager's decision-making style was tested through managerial accounting. The results indicated a significant indirect effect $(\mathrm{p}=0.000)$ and showed the mediating role of managerial accounting. The indirect effect of 0.062 is obtained by multiplication of direct paths $\beta 1=0.245$ and $\beta 2=0.252$, as presented in Table 4. Lastly, the direct and indirect effects were analysed to assess whether this mediation was complete or partial, and the results indicated that the mediation was partial (Table 5). 
Table 5: Structural model results - hypothesis testing

\begin{tabular}{|l|l|l|l|}
\hline Effects & Estimates & Two-Tailed Significance & Bias corrected confidence interval (95\%) \\
Indirect Effects & 0.062 & 0.000 & $0.030-0.108$ \\
Direct Effect & 0.155 & 0.005 & $0.046-0.263$ \\
\hline
\end{tabular}

Empirical findings from this study are consistent with theoretical expectations and results of studies in the for-profit sector. Findings on the positive influence of the analytical and proactive manager's decision-making style on the application of managerial accounting are compatible with the findings in profit organizations $[10,29,5]$. In addition, evidence in this study of the positive influence of managerial accounting on the level of community engagement (a proxy for non-profits organizational performance) is consistent with similar studies in the for-profit sector $[32,22,21,27,31]$. Although the concept of performance is different in the non-profit sector in contrast to the for-profit sector in the aforementioned studies, the basic logic is analogous. The results confirm that the information provided by the managerial accounting system has the potential to increase the efficiency of non-profit as well as in the for-profit sector.The study also finds an indirect effect between the analytical and proactive manager's decision-making style and success in community engagement through managerial accounting. It illustrates the potential of the analytical and proactive manager's decision-making style and managerial accounting to improve the non-profit's community engagement. Managers in non-profit organizations need to adopt techniques used in managerial accounting as they represent the solutions to the improved performance of non-profit organizations.

\section{Conclusion}

This study provides several interesting results. First, the analytical and proactive manager's decision-making style identified as the contingency factor is positively associated with managerial accounting in non-profit organizations. Second, the findings provide evidence that managerial accounting enhances the performance of non-profit organizations, approximated by the success in community engagement. Finally, this study reveals the mediating role of managerial accounting between an executive's decision-making style and the performance of non-profit organizations.

The SEM analysis provides evidence that the manager's decision-making style and application of managerial accounting techniques enhance the performance of non-profit organizations. These findings suggest that non-profit organizations should specifically prioritize the implementation of managerial accounting techniques to help them improve a particular dimension of the non-profit's organizational performance, i.e., success in community engagement.

There are some limitations to this study that should be considered. First, the data were collected at a single point in time. It is recommended that future studies examine longitudinal data to evaluate if managerial accounting continues to mediate the relation between analytical and proactive leadership style and community engagement over an extended period. Second, other contingency factors have not been captured in the model in this study. Future studies in the non-profit sector could consider contingency factors such as environmental uncertainty, technology, organizational structure, organizational strategy, etc. Third, this study used a particular dimension of the non-profit's organizational performance, i.e., success in community engagement. The concept of performance in the non-profit sector still has different meanings. Future studies could investigate other dimensions of the performance of non-profit organizations. This study is also a call for further attempts to advance the operationalization of the concept of performance in the non-profit sector. Future research in the non-profit sector can explore more contingency factors relating to managerial accounting adoption that support different 
dimensions of performance of non-profit organizations and improve the SEM modelling by a more complex model with more variables. The mentioned limitations do not reduce the contribution of this study, although the derived conclusions have to be taken with caution.

This study contributes to managerial accounting research in the non-profit sector and responds to recent calls to investigate the direct and indirect effects of managerial accounting in non-profit organizations. By using SEM, this research also significantly contributes to the research methodology on managerial accounting research in the non-profit sector.

\section{References}

[1] Awang, Z. (2012). A handbook on SEM. Structural equation modeling.

[2] Bouwens, J., Abernethy, M. A. (2000). The consequences of customization on management accounting system design. Accounting, Organizations and Society, 25(3), 221-241. doi: 10.1016/S0361-3682(99)00043-4

[3] Byrne, B. M. (2016). Structural equation modeling with AMOS: basic concepts, applications, and programming (multivariate applications series). New York: Taylor \& Francis Group.

[4] Cadez, S., Guilding, C. (2008). An exploratory investigation of an integrated contingency model of strategic management accounting. Accounting, organizations and society, 33(7-8), 836-863. doi: 10.1016/j.aos.2008.01.003

[5] Chenhall, R. H. (2003). Management control systems design within its organizational context: findings from contingency-based research and directions for the future. Accounting, organizations and society, 28(2-3), 127-168. doi: 10.1016/S0361-3682(01)00027-7

[6] Colbran, R., Ramsden, R., Stagnitti, K., Adams, S. (2018). Measures to assess the performance of an Australian non-government charitable non-acute health service: a Delphi survey of Organisational stakeholders. Health services management research, 31(1), 11-20. doi: $10.1177 / 0951484817725681$

[7] Connor, P. E., Becker, B. W. (2003). Personal value systems and decision-making styles of public managers. Public Personnel Management, 32(1), 155-180. doi: 10.1177/009102600303200109

[8] De Lautour, V. J. (2018). Strategic Management Accounting, Volume II: Beyond the Numbers (Vol. 2).Springer.

[9] Eldenburg, L., Krishnan, R. (2006). Management accounting and control in health care: an economics perspective. Handbooks of management accounting research, 2, 859-883. doi: 10.1016/S1751-3243(06)02016-5

[10] Gordon L.A., Miller D. (1976) A contingency framework for the design of accounting information systems. In: Emmanuel C., Otley D., Merchant K. (eds) Readings in Accounting for Management Control. Springer, Boston, MA. (pp. 569-585). doi: 10.1007/978-1-4899-7138-8_26

[11] Hair, J. F., Black, W. C., Babin, B. J., Anderson, R. E. (2009). Multivariate Data Analysis 7th Edition Pearson Prentice Hall.

[12] Henderson, E., Lambert, V. (2018). Negotiating for survival: Balancing mission and money. The British Accounting Review, 50(2), 185-198. doi: 10.1016/j.bar.2017.12.001

[13] Herman, R. D., Renz, D. O. (2008). Advancing non-profit organizational effectiveness research and theory: Nine theses. Non-profit management and leadership, 18(4), 399-415. doi: 10.1002/nml.195

[14] Hopper, T., Bui, B. (2016). Has management accounting research been critical?. Management Accounting Research, 31, 10-30. doi: 10.1016/j.mar.2015.08.001

[15] Hoque, Z. (2004). A contingency model of the association between strategy, environmental uncertainty and performance measurement: impact on organizational performance. International business review, 13(4), 485-502. doi: 10.1016/j.ibusrev.2004.04.003

[16] Hoyle, R. H. (Ed.). (2012). Handbook of structural equation modeling. Guilford Press.

[17] Ip, P. C., Li, P. W., Yau, J. S. (2003). Application of activity based costing (ABC): the case of a non-government organization. International Journal of Management, 20(3), 282.-293.

[18] King, R., Clarkson, P. M., Wallace, S. (2010). Budgeting practices and performance in small healthcare businesses. Management Accounting Research, 21(1), 40-55. doi: 10.1016/j.mar.2009.11.002

[19] Kline, R. B. (2015). Principles and practice of structural equation modeling. Guilford publications. 
[20] Libby, R., Lewis, B. L. (1977). Human information processing research in accounting: The state of the art. Accounting, Organizations and Society, 2(3), 245-268. doi: 10.1016/0361-3682(82)90004-6

[21] Macinati, M. S., Anessi-Pessina, E. (2014). Management accounting use and financial performance in public health-care organisations: Evidence from the Italian National Health Service. Health Policy, 117(1), 98-111. doi: 10.1016/j.healthpol.2014.03.011

[22] Mahama, H., Cheng, M. M. (2013). The effect of managers' enabling perceptions on costing system use, psychological empowerment, and task performance. Behavioral Research in Accounting, 25(1), 89-114. doi: $10.2308 /$ bria-50333

[23] Mitchell, G. E. (2013). The construct of organizational effectiveness: Perspectives from leaders of international nonprofits in the United States. Nonprofit and Voluntary Sector Quarterly, 42(2), 324-345. doi: 10.1177/0899764011434589

[24] Nitzl, C. (2016). The use of partial least squares structural equation modelling (PLS-SEM) in management accounting research: Directions for future theory development. Journal of Accounting Literature, 37, 19-35. doi: 10.1016/j.acclit.2016.09.003

[25] Pizzini, M. J. (2006). The relation between cost-system design, managers' evaluations of the relevance and usefulness of cost data, and financial performance: an empirical study of US hospitals. Accounting, Organizations and Society, 31(2), 179-210. doi: 10.1016/j.aos.2004.11.001

[26] Ryan, C., Irvine, H. (2012). Accountability Beyond the Headlines: Why Not-for-profit Organisations Need to Communicate Their Own Expenditure Stories. Australian Accounting Review, 22(4), 353-370. doi: 10.1111/j.1835-2561.2012.00192.x

[27] Spekle, R. F., Verbeeten, F. H. (2014). The use of performance measurement systems in the public sector: Effects on performance. Management Accounting Research, 25(2), 131-146. doi: 10.1016/j.mar.2013.07.004

[28] Teeratansirikool, L., Siengthai, S., Badir, Y., Charoenngam, C. (2013). Competitive strategies and firm performance: the mediating role of performance measurement. International Journal of Productivity and Performance Management. 62(2), 168-184. doi: 10.1108/17410401311295722

[29] Thomas, A. P. (1991). Towards a contingency theory of corporate financial reporting systems. Accounting, Auditing and Accountability Journal, 4(4), 40-57. doi: 10.1108/EUM0000000001933

[30] Thompson, B. (2004). Exploratory and confirmatory factor analysis. Washington, American Psychological Association.

[31] Uyar, A., Kuzey, C. (2016). Contingent factors, extent of budget use and performance: A structural equation approach. Australian Accounting Review, 26(1), 91-106. doi: 10.1111/auar.12090

[32] Verbeeten, F. H. (2008). Performance management practices in public sector organizations: Impact on performance. Accounting, Auditing and Accountability Journal, 21(3), 427-454. doi: $10.1108 / 09513570810863996$

[33] Wadongo, B., Abdel-Kader, M. (2014). Contingency theory, performance management and organisational effectiveness in the third sector. International Journal of Productivity and Performance Management. 63(6), 680-703. doi: 10.1108/IJPPM-09-2013-0161

[34] Winand, M., Vos, S., Claessens, M., Thibaut, E., Scheerder, J. (2014). A unified model of nonprofit sport organizations performance: perspectives from the literature. Managing leisure, 19(2), 121-150. doi: 10.1080/13606719.2013.859460 